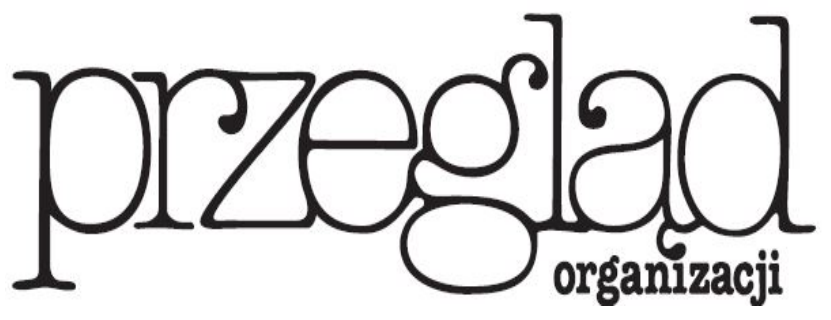

Miesięcznik TNOiK

Założył Karol Adamiecki w 1926 r.

\title{
WYBRANE CZYNNIKI OGRANICZAJĄCE SKUTECZNOŚĆ ZARZADDANIA SZPITALAMI PUBLICZNYMI
}

https://doi.org/10.33141/po.2019.05.08

Piotr Lenik
Przegląd Organizacji, Nr 5 (952), 2019, ss. 57-63 www.przegladorganizacji.pl @Towarzystwo Naukowe Organizacji i Kierownictwa (TNOiK)

\section{Wprowadzenie}

W

ostatnich latach obserwuje się wzrost zainteresowania badaniami dotyczącymi identyfikacji różnego rodzaju barier i ograniczeń występujących $\mathrm{w}$ praktyce funkcjonowania podmiotów ochrony zdrowia. Analiza literatury przedmiotu pozwala na stwierdzenie, że stosunkowo duża część spośród dostępnych rodzimych badań identyfikuje bezpośrednio lub pośrednio niedomagania - występujące albo 
ogólnie $\mathrm{w}$ systemie opieki zdrowia, albo na poziomie poszczególnych podmiotów, w tym m.in. w kontekście efektywności ekonomicznej (Porębski, 2015), barier utrudniających kształtowanie innowacyjnej kultury organizacyjnej (Jończyk, 2011; 2012), przedsiębiorczości publicznej i innowacyjności (Głód, 2016a; 2016b), wdrażania zmian (Jasińska, 2015). Pewna liczba krajowych publikacji skupia się na możliwościach poprawiania zidentyfikowanych niedostatków (m.in. Z. Nęcki, M. Kęsy, Ł. Sułkowski, B. Kożuch, A. Frączkiewicz-Wronka, A. Głowacka, E. Mojs, E. Marcinkowska, J. Klich, M. Hass-Symotiuk, R. Lewandowski, B. Ziębicki, M. Bugdol i inni). Jednakże jedynie wąska grupa opracowań uwzględnia przyczynowo-skutkowy kontekst ograniczeń zarządzania w szpitalach publicznych w szczególności dotyczących obszaru zasobów ludzkich (m.in. B. Buchelt, J. Jończyk, J. Moczydłowska, M. Kautsh i inni).

Należy zauważyć, że niedostatki w tej sferze mogą się przyczyniać m.in. do niezamierzonego przez badaczy upraszczania dotyczącego założeń, wniosków lub rekomendacji - na etapie ich formułowania, a nawet deformowania interpretacyjnego zjawisk zachodzących $\mathrm{w}$ obszarach związanych $\mathrm{z}$ zarządzaniem podmiotami leczniczymi. W badaniach niejednokrotnie pomijana jest specyficzność implikująca skuteczność zarządzania szpitalami publicznymi, rozumiana ogólnie jako dążenie do przetrwania organizacji oraz utrzymania jej w dobrej kondycji finansowej (Stoner, Wankel, 1997, s. 45; Gilbert i in., 2011, s. 24). Specyficzność ta wynika m.in. z turbulentności otoczenia, w którym funkcjonują, nieprzewidywalności i zmienności zachowań poszczególnych interesariuszy (często z przeciwstawnymi lub sprzecznymi oczekiwaniami), istnienia w realiach niepełnej konkurencji rynkowej pozostającej pod silnym wpływem politycznym, permanentnego niedofinansowania wynikającego $\mathrm{z}$ faktu, że nakłady na ochronę zdrowia $\mathrm{w}$ Polsce są aktualnie jednymi $\mathrm{z}$ najniższych w Europie (Health at Glance Report - Europe, 2018), a także ukształtowanej na przestrzeni lat kultury organizacyjnej szpitali z orientacją na status quo (Sułkowski, 2013, s. 85 i dalej). Tymczasem powyższe czynniki mogą mieć istotny wpływ na zarządzanie w szpitalach publicznych, w tym czynnikiem ludzkim, oraz na realne ograniczenia w skuteczności zarządzania tym zasobem. W tym względzie może bowiem występować silne inhibicyjne oddziaływanie otoczenia zewnętrznego i wewnętrznego na skuteczność zarządczą, a w pewnych okolicznościach również na autonomię i racjonalność decyzyjną kierowników szpitali.

Celem artykułu jest więc próba zwrócenia uwagi na wybrane czynniki determinujące ograniczenia w zarządzaniu szpitalami publicznymi poprzez postawienie tezy, że pewne dysfunkcje mogą być wynikiem innych elementów, niż mogłoby się to wydawać na podstawie analizy nieuwzględniającej wszystkich okoliczności mogących mieć wpływ na dany stan rzeczy, w tym przede wszystkim zależności przyczynowo-skutkowych. Metoda tutaj wykorzystana opiera się na syntetycznym połączeniu wyników dotychczasowych krajowych badań dostępnych w źródłach bibliograficznych $\mathrm{z}$ własnymi obserwacjami autora $\mathrm{w}$ zakresie przedmiotowej problematyki, w tym wynikającymi z kilkuletnich badań realizowanych na terenie całego kraju, m.in. w zakresie identyfikowania czynników ograniczających m.in. autonomię decyzyjną i efektywność zarządczą. Decyzja autora co do potrzeby identyfikacji poszczególnych czynników mogących mieć inhibicyjny wpływ na zarządzanie w szpitalach publicznych jest przy tym zbieżna $z$ jedną ze sformułowanych jeszcze w latach dwudziestych XX w. przez E. Hauswalda ogólnych metod organizatorskich, opisanych po raz pierwszy w 1929 r. na łamach „Czasopisma Technicznego", według której pomiędzy różnymi zjawiskami występującymi w organizacjach istnieją związki przyczynowo-skutkowe bezpośrednio lub pośrednio na nie wpływające oraz determinujące ich kształt.

Założony cel, uwzględniający identyfikację czynników mogących negatywnie wpływać na skuteczność zarządzania szpitalami publicznymi, wpisuje się $\mathrm{w}$ ugruntowany $\mathrm{w}$ polskim piśmiennictwie nurt diagnostyczno-funkcjonalny podejścia organizatorskiego, traktujący organizację przez pryzmat możliwości usprawniania dotychczas funkcjonującego systemu poprzez identyfikację, diagnozę i ocenę stanu istniejącego, wykrywanie wszelkich nieprawidłowości, a w dalszej kolejności - rekomendację lub zaprojektowanie i wdrożenie niezbędnych usprawnień (Martyniak, 1987, s. 155). W tym podejściu jednym z kluczowych celów stawianych przed menedżerami jest zwiększanie efektywności, w tym pracowników, gdzie w sekwencyjnym ujęciu efektów organizacyjnych przyjmuje się, że wyniki kadrowe (określne zdolnościami, wiedzą, umiejętnościami, postawami itp.) mają bezpośredni wpływ na wyniki operacyjne (wydajność, efektywność procesów, jakość usług itp.), które z kolei implikują wyniki finansowe.

\section{Ogólne czynniki wpływające na specyfikę zarządzania w szpitalach publicznych}

Ẃród czynników wpływających na ograniczenia pracy zarządzających szpitalami znawcy badający tę problematykę wymieniają m.in. (Anthony, Young, 1998, s. 54 i dalej):

- marginalizowanie znaczenia wyniku finansowego jako miary działalności podmiotu, ale również poszczególnych oddziałów szpitalnych, co może utrudniać lub wypaczać ocenę dokonań poszczególnych podmiotów oraz kierowników nimi zarządzających,

- szczególne uwarunkowania prawne w zakresie funkcjonowania podmiotów leczniczych oraz ich odpowiedzialności, 
- brak stabilności dla stanowiska kierownika podmiotu publicznego, co może ujemnie wpływać m.in. na autorytet dyrektorów szpitali publicznych,

- nieformalne ograniczania przez organ tworzący decyzji kierownika w zakresie wyborów celów i strategii, w szczególności obserwowane w obszarze decyzji kadrowych,

- niewielką bezpośrednią zależność finansową od pacjentów korzystających ze świadczeń zdrowotnych,

- dominację wśród zatrudnionej kadry samodzielnych pracowników, z kompetencjami w zakresie podejmowania autonomicznych decyzji, które istotnie mogą wpływać na wydatki oraz przychody, - rozproszenie odpowiedzialności (rząd i ministerstwo zdrowia określają zasady funkcjonowania systemu, publiczny płatnik reglamentuje środki w oparciu o własne kalkulacje, organ tworzący administracyjnie nadzoruje podległe podmioty, kierownik jednoosobowo ponosi odpowiedzialność za zarządzanie publicznym szpitalem i jego efektywność ekonomiczną i organizacyjną),

- duże zróżnicowanie pod wieloma względami zatrudnionej kadry, mogące powodować występowanie antagonizmów na wielu różnych płaszczyznach, - silne inhibicyjne wpływy polityczne na wszystkich poziomach władzy, mogące wpływać m.in. na kształtowanie specyficznej kultury organizacyjnej szpitali publicznych zorientowanych na status quo. Spośród innych ogólnych czynników mogących $\mathrm{w}$ istotny sposób determinować ograniczenia w obszarze zarządzania publicznymi szpitalami warto wskazać pewne inhibitory systemowe (por. badania Instytutu Organizacji Ochrony Zdrowia Uczelni Łazarskiego, 2013, s. 11 i dalej), m.in. syndrom określany jako „zła konkurencja” (konkurowanie zbyt wielu podmiotów o a priori ograniczone zasoby finansowe i kadrowe, wywołując efekt rozdrobnienia kontraktów oraz rosnące roszczenia płacowe ze strony kadry medycznej), a także syndrom określany mianem "marnotrawstwa systemowego” (m.in. pozbawienie możliwości wykorzystania przez podmioty lecznicze swoich wolnych zasobów osobowych i rzeczowych, które mogłyby zostać użyte do udzielania świadczeń zdrowotnych finansowanych przez podmioty inne niż płatnik publiczny). Dodatkowy element mogący mieć wpływ na specyfikę zarządzania w szpitalach publicznych może stanowić syndrom, który można byłoby nazwać „dysfunkcjonalnością systemową" lub „negatywną instytucjonalizacją". Przy czym instytucjonalizacja rozumiana jest tutaj jako proces przechodzenia od niesformalizowanych sposobów działania społecznego do uregulowanych, względnie stałych form aktywności, podlegających społecznym sankcjom. To także nadanie charakteru instytucji istniejącym już wcześniej form działania, dzięki czemu stają się one obowiązujące. To również społeczne utrwalenie się jakiejś wartości, jakiegoś faktu, zwyczaju - istotnych dla trwania i rozwoju danej zbiorowości (Słownik PWN, 1996, s. 747).
Instytucjonalizowanie oznacza formowanie, kształtowanie, organizowanie się, powstawanie, tworzenie, zawiązywanie się. Instytucjonalizacja niejako więc usankcjonuje coś, co wcześniej było nieformalne, ale stanowiło już pewien kanon, standard zachowań, dominującą postawę. W organizacjach niejednokrotnie można spotkać rozumianą w powyżej opisany sposób „instytucjonalizację”, która może wywoływać zarówno pozytywne skutki (np. powstawanie procedur usprawniających funkcjonowanie konkretnych obszarów organizacyjnych), jak i negatywne - np. w sytuacji, gdy pozytywne zaangażowanie staje się anomalią i jest negowane przez ogół pracowników. Wówczas można zaobserwować coś, co mogłoby być określone mianem negatywnej lub ujemnej instytucjonalizacji, stanowiącej de facto nieformalne usankcjonowanie niewłaściwego $\mathrm{z}$ obiektywnego punktu widzenia wzorca zachowań. Za pewien przykład mogą tutaj służyć dosyć powszechnie identyfikowane $\mathrm{w}$ minionym systemie gospodarczym praktyki spożywania alkoholu w miejscu pracy albo „wynoszenia” przez pracowników z zakładu pracy różnych części, materiałów czy gotowych produktów. Oczywiście, z dzisiejszego punktu widzenia takie zachowania rozpatrywane byłyby w kategoriach czynów kwalifikujących się co najmniej do zwolnienia dyscyplinarnego. Ale $\mathrm{z}$ perspektywy realiów gospodarki centralnie planowanej były czymś, co nie wzbudzało w społeczności drastycznych kontrowersji. Przywoływane zachowania pewnej części ówczesnego społeczeństwa, pomijając kwestie moralne, mogły wynikać z realiów organizacyjnych i uwarunkowań systemowych: niedostatecznego szacunku ludzi do pracy (lub do systemu politycznego i gospodarczego), braku stawianych przez kadrę kierowniczą wymagań efektywnościowych w niemal całej gospodarce, braku piętnowania podobnych praktyk, dosyć powszechnej tolerancji dla tego typu patologii. Pracownicy prawdopodobnie nawet nie byli do końca świadomi, że w przedmiotowych zachowaniach jest coś nagannego, a nawet kryminogennego. Niemniej różnorodne postawy, identyfikowane nie tylko w kontekście podejścia do szeroko rozumianego klienta, wykonywania obowiązków pracowniczych, dbałości o mienie, zaangażowania kadry, jej lojalności w stosunku do swojego miejsca pracy oraz pracodawcy, ale także inne - mogą być $\mathrm{w}$ pewnym sensie i w pewnych okolicznościach przykładami negatywnej (lub ujemnej) instytucjonalizacji zachowań organizacyjnych, dotyczącymi co najmniej części podmiotów z konotacjami funkcjonowania $\mathrm{w}$ minionym systemie, $\mathrm{w}$ tym również szpitali publicznych (por. wyniki badań Instytutu Organizacji Ochrony Zdrowia Uczelni Łazarskiego, 2013, s. 27-28; Golinowska, 2005, s. 129).

Należy także zauważyć, że na skuteczność zarządzania czynnikiem ludzkim w szpitalach publicznych niemały wpływ mogą mieć uwarunkowania kulturowe, w tym te niejako "zaadaptowane” $\mathrm{z}$ otoczenia zewnętrznego, które - w myśl koncepcji traktującej 
organizację jako system otwarty (Koźmiński, Piotrowski, 2002, s. 31; Urbanowska-Sojkin i in., 2007, s. 17) - przenikają przez umowną granicę do wnętrza organizacji. Można dostrzec tutaj pewną interaktywność kształtowania i oddziaływania kultury organizacyjnej szpitali publicznych. Dzieje się tak dlatego, że kultura organizacyjna jest niewidoczną siecią głęboko zakorzenionych w organizacji znaczeń, nadaje każdej organizacji wyjątkową tożsamość, a także wpływa na zachowania pracowników. Powstaje ona na fundamentach dominujących wartości, postaw i zachowań pracowników oraz dominujących wartości, postaw i zachowań pracowników oraz przeważających postaw i zachowań interesariuszy zewnętrznych (Szwiec, 2012, s. 9). Możliwe więc jest mówienie o kulturze otoczenia zewnętrznego, która wpływa pozytywnie lub negatywnie na całokształt danej organizacji. Przy czym zauważa się, że siła oddziaływania otoczenia na szpitale może być większa niż szpitali na otoczenie (Frączkiewicz-Wronka, Szymaniec, 2012, s. 218), a ujemny wpływ interesariuszy zewnętrznych na dany obszar organizacyjny lub cały podmiot może być traktowany jako ograniczenie (Sułkowski i in., 2012, s. 122-123).

Wśród czynników mogących mieć wpływ na skuteczność zarządzania w szpitalach publicznych należy także wymienić m.in. poziom nakładów na ochronę zdrowia, które na tle krajów OECD są jednym z najniższych (OECD Health Statistic 2017; Health at Glance Report - Europe 2018), koszty pracy, stanowiące najpoważniejszy składnik wydatków ogółem, wpływające m.in. na wyniki finansowe oraz możliwości inwestycyjne podmiotów leczniczych (dane Ministerstwa Zdrowia), a także inne.

\section{Wybrane różnice w zarządzaniu szpitalami publicznymi i szpitalami niepublicznymi}

t ącznie w Polsce jest około 900 szpitali, chociaż L w różnych źródłach dostrzec można tutaj pewne rozbieżności (Golinowska, 2012, s. 113 i 115). Na przykład według Raportu „500 największych szpitali w Polsce”, opublikowanego w grudniu 2016 roku przez Puls Medycyny, w 2015 roku na świadczenia szpitalne podpisało umowy z NFZ ponad 1000 podmiotów. Zdecydowaną większość wśród tych podmiotów stanowią jednostki publiczne. Dysponują one około $90 \%$ wszystkich łóżek szpitalnych, aktualnie szacowanych na poziomie około 200 tysięcy (Golinowska, 2012, s. 113-114). Z Rejestru Podmiotów Wykonujących Działalność Leczniczą prowadzonego przez Centrum Systemów Informacyjnych Ochrony Zdrowia wynika, że w grupie małych szpitali (do 150 łóżek), stanowiących około $50 \%$ wszystkich podmiotów, dominują jednostki prywatne. W grupie szpitali o średniej wielkości (151-500 łóżek) przeważają podmioty publiczne. Natomiast wśród największych szpitali (powyżej 500 łóżek), stanowiących około $11 \%$ ogółu podmiotów, identyfikuje się niemal wyłącznie placówki publiczne (Golinowska, 2012, s. 115).

Wydaje się, że w rozważaniach naukowych zbyt rzadko podnoszona jest kwestia różnic dotyczących funkcjonowania szpitali publicznych od podmiotów niepublicznych, pomimo działania $w$ tych samych realiach rynkowych i realizowania podobnych zadań w obrębie systemu ochrony zdrowia. Tymczasem tylko wyłącznie w obszarze zarządzania czynnikiem ludzkim występują istotne różnice. Różnice między podmiotami publicznymi a niepublicznymi determinują m.in. uwarunkowania w zakresie systemów zarządzania oraz konsekwencji $\mathrm{z}$ tego wynikających. W sektorze publicznym pracownicy zatrudnieni są przede wszystkim w formie najbardziej dla nich stabilnej, tzn. umów o pracę na czas nieokreślony, a fluktuacja kadry jest niewielka. Pracodawcy niepubliczni z kolei preferują formy mniej stabilne dla pracowników, tj. kontrakty, umowy czasowe czy umowy cywilnoprawne, a fluktuacja kadr jest tam na ogół wyższa. Poprzez tę różnicę w podmiotach publicznych pracownicy mogą mieć mniejsze poczucie zagrożenia utraty pracy, a poprzez to brak jest tam presji w kierunku celowych lub koniecznych zmian, w tym w obszarze poprawy efektywności organizacyjnej i ekonomicznej podmiotów. W części przypadków może tam również występować syndrom braku autorytetu wobec zarządzających (m.in. ze względu na niestabilność funkcji dyrektora szpitala). Dodatkowo, istotny wpływ interesariuszy oraz nierzadko obserwowane niekonsekwentne, a nawet wzajemnie sprzeczne postawy ze strony decydentów, w tym organów tworzących, mogą powodować, że w publicznych podmiotach, które są nierentowne, dominuje status quo w wielu obszarach zarządczych (Sułkowski i in., 2012, s. 127).

Zauważa się przy tym, że wśród różnorodnych ograniczeń towarzyszących skuteczności oddziaływania na pracowników w szpitalach publicznych w skrajnych przypadkach mogą występować całkowicie nieelastyczne systemy zarządzania zasobami ludzkimi charakteryzujące się stabilnością zatrudnienia nawet najmniej efektywnych pracowników, etatyzmem, brakiem rotacji kadry, syndykalizmem oraz znacznym uzwiązkowieniem pracowników, a także brakiem efektywnego systemu motywowania i premiowania (Sułkowski i in., 2012, s. 123). W podmiotach z kapitałem prywatnym $\mathrm{z}$ oczywistych względów podobne sytuacje na ogół nie występują.

Podstawowe różnice $\mathrm{w}$ zarządzaniu szpitalami publicznymi i niepublicznymi mogą wynikać również m.in. $\mathrm{z}$ tego, że podmioty prywatne koncentrują się na rentownych procedurach medycznych, natomiast publiczne systemowo realizują wszystkie świadczenia, w tym w dużej mierze kosztochłonne, nierentowne, generujące straty finansowe (co m.in. wpływa na efektywność ekonomiczną). Różnice te wzmacnia również odnotowywane przez wielu badaczy spostrzeżenie, że 
Tabela 1. Wybrane różnice pomiędzy szpitalami publicznymi i niepublicznymi wpływające m.in. na skuteczność zarządzania

\begin{tabular}{|c|c|}
\hline Szpitale publiczne & Szpitale niepubliczne \\
\hline $\begin{array}{l}\text { Obecne w świadomości społecznej przekonanie, że } \\
\text { publiczna opieka zdrowia funkcjonuje gorzej niż } \\
\text { prywatna }\end{array}$ & $\begin{array}{l}\text { Obecne w świadomości społecznej przekonanie, } \\
\text { że prywatne podmioty funkcjonują lepiej niż } \\
\text { „państwowe” }\end{array}$ \\
\hline $\begin{array}{l}\text { Duży wpływ lobby poszczególnych grup } \\
\text { zawodowych, w tym przede wszystkim medycznych }\end{array}$ & $\begin{array}{l}\text { Umiarkowany lub niewielki wpływ lobby } \\
\text { poszczególnych grup zawodowych }\end{array}$ \\
\hline $\begin{array}{l}\text { Dominacja nieelastycznych form zatrudnienia } \\
\text { kadry }\end{array}$ & Dominacja elastycznych form zatrudnienia kadry \\
\hline Duży wpływ organizacji związkowych & Minimalne znaczenie organizacji związkowych \\
\hline $\begin{array}{l}\text { Ograniczana autonomia decyzyjna kierownika } \\
\text { wskutek nakładania się na siebie uwarunkowań } \\
\text { ekonomicznych ze społeczno-politycznymi }\end{array}$ & $\begin{array}{l}\text { Pełna decyzyjność kierownika w obszarze } \\
\text { ekonomicznym }\end{array}$ \\
\hline $\begin{array}{l}\text { Znaczna ingerencja ze strony interesariuszy, w tym } \\
\text { otoczenia politycznego }\end{array}$ & $\begin{array}{l}\text { Umiarkowana lub niewielka ingerencja ze strony } \\
\text { interesariuszy, w tym otoczenia politycznego }\end{array}$ \\
\hline $\begin{array}{l}\text { Obarczenie konsekwencjami poprzedniego } \\
\text { systemu gospodarczego w obszarach m.in. kultury } \\
\text { organizacyjnej, rozbudowanej administracji, } \\
\text { przerostów zatrudnienia w poszczególnych } \\
\text { grupach zawodowych, utrzymania nienowoczesnej, } \\
\text { kosztochłonnej infrastruktury, nadmiernych } \\
\text { kosztów osobowych }\end{array}$ & $\begin{array}{l}\text { Brak obarczenia konsekwencjami poprzedniego } \\
\text { systemu gospodarczego - nowe podmioty } \\
\text { zorganizowane są w sposób racjonalny }\end{array}$ \\
\hline $\begin{array}{l}\text { Wszelkie próby wprowadzania wewnętrznych } \\
\text { zmian łączą się ze znacznym zainteresowaniem tzw. } \\
\text { opinii publicznej }\end{array}$ & $\begin{array}{l}\text { Stosunkowo mniejsze zainteresowanie tzw. opinii } \\
\text { publicznej wprowadzanymi wewnątrz organizacji } \\
\text { zmianami }\end{array}$ \\
\hline
\end{tabular}

Źródło: Lenik, 2017, s. 46-47

w szpitalach publicznych na przestrzeni lat ukształtowała się kultura organizacyjna determinująca niską wrażliwość na zmiany, w tym w obszarze zarządzania kapitałem ludzkim. Problemem wydaje się niestabilność w pracy na stanowiskach dyrektorów szpitali publicznych, co może mieć niebagatelne znaczenie $\mathrm{z}$ punktu widzenia istoty autorytetu menedżerów.

W tabeli 1 przedstawiono wybrane różnice determinujące funkcjonowanie szpitali publicznych i niepublicznych.

Należy także zwrócić uwagę na inne determinanty mogące wpływać na skuteczność zarządzania w szpitalach publicznych, oddziałujące m.in. w obszarach: finansowym, kulturowym i społecznym, w tym (Lenik, 2017, s. 47-48):

- występowanie zjawiska niedoszacowania wielu procedur medycznych, które są realizowane przez szpitale publiczne oraz brak zainteresowania ze strony podmiotów prywatnych funkcjonowaniem $\mathrm{w}$ obszarze nierentownych procedur medycznych;

- rozdrobnienie kontraktów w obszarze poszczególnych świadczeń medycznych na zbyt wiele podmiotów (kontrakty nieuwzględniające rzeczywistych możliwości realizacji świadczeń przez poszczególne szpitale), co uniemożliwia uzyskanie efektu skali, a jednocześnie generuje wysokie koszty stałe u podmiotów je realizujących;
- brak decyzyjności na poziomie centralnym w zakresie zoptymalizowania i zobiektyzowania rzeczywistych potrzeb zdrowotnych (niepopularne decyzje musiałyby dotknąć m.in. części funkcjonujących szpitali i pracującej tam kadry);

- brak zgody lobby branżowego oraz aprobaty społecznej (a przez to woli politycznej) na ograniczanie kosztów pracy w szpitalach publicznych wynikających m.in. $z$ obiektywnego przerostu zatrudnienia w stosunku do porównywalnych podmiotów prywatnych (istnieją szpitale, w których nawet $80 \%$ kosztów generują płace, stąd w oczywisty sposób brakuje środków na działalność rozwojową, a nawet na działalność bieżącą);

- powszechnie funkcjonujące $\mathrm{w}$ szpitalach publicznych nienowoczesne i mało motywacyjne systemy wynagradzania, w tym w przypadku medycznych grup zawodowych;

- istniejące w pewnym zakresie negatywne praktyki związane m.in. $\mathrm{z}$ taktowaniem pracy w publicznej ochronie zdrowia przez pryzmat płatnika składek ubezpieczeniowych czy możliwości dostępu do wysoko specjalistycznego kosztownego sprzętu;

- przypadki braku podejścia menedżerskiego do zarządzania, w tym strategicznego, w części szpitali publicznych (m.in. ograniczanie się menedżerów 
do administrowania szpitalem bądź koncentrujących się wyłącznie na celach bieżących lub krótkookresowych $\mathrm{z}$ jednoczesnym pielęgnowaniem jak najlepszych relacji osobistych $\mathrm{z}$ otoczeniem politycznym oraz dostosowywanie swoich działań do aktualnie spodziewanych oczekiwa $\mathrm{n}$ ze strony tego otoczenia);

- dominująca w szpitalach publicznych specyficzna kultura organizacyjna zakorzeniona w poprzednim systemie gospodarczym, co wpływa na postawy, zachowania czy motywację pracowników, a w konsekwencji na skuteczność zarządczą kierowników tych podmiotów;

- brak realnej stabilności na stanowisku kierownika szpitali; ograniczona samodzielność decyzyjna menedżerów szpitali publicznych oraz nie zawsze merytoryczne oddziaływanie poszczególnych interesariuszy wewnętrznych i zewnętrznych (obserwowany wśród menedżerów publicznej ochrony zdrowia syndrom „dyrektora szpitala publicznego, którego łatwiej jest zwolnić od portiera" w związku z nieodosobnionymi przypadkami decyzji politycznych niepowiązanych z obiektywną oceną wyników pracy menedżera oraz zarządzanego podmiotu).

\section{Podsumowanie}

W ydaje się, że skuteczność zarządzania w szpitalach publicznych zależy od wielu składowych. Należy przy tym stwierdzić, że błędnym z założenia może być dokonywanie bezpośredniego porównywania szpitali publicznych i niepublicznych (np. pod względem szerokorozumianej efektywności) bez uwzględnienia potencjalnych różnic pomiędzy uwarunkowaniami, w których one funkcjonują, pomimo spełniania tej samej funkcji w systemie ochrony zdrowia oraz działania na tym samym rynku usług zdrowotnych. Różnice, często nieświadomie pomijane przez badaczy, dotyczą m.in. tego, że podmioty z kapitałem prywatnym koncentrują się przede wszystkim na rentownych procedurach medycznych, natomiast publiczne systemowo realizują wszystkie świadczenia, $w$ tym $w$ istotnym zakresie kosztochłonne, nierentowne, generujące straty finansowe (co niejako $\mathrm{z}$ góry może przesądzać o różnicach $\mathrm{w}$ efektywności ekonomicznej). Inna zasadnicza różnica może dotyczyć tego, że w podmiotach publicznych, w przeciwieństwie do podmiotów niepublicznych, ze względu na utrzymujący się tam od lat status quo w obszarze zasobów pracowniczych (na co może mieć wpływ m.in. oddziaływanie różnorodnych czynników otoczenia, w tym politycznego), przeważają nieelastyczne formy zatrudnienia, dominuje etatyzm oraz stabilność zatrudniania, występuje silne uzwiązkowienie, w ograniczony sposób ma zastosowanie selekcja pracowników uwzględniająca efektywność i skuteczność ich pracy, a przy tym koszty osobowe są tam wyższe niż w przypadku niepublicznych konkurentów (co często może przesądzać o różnicach w efektywności organizacyjnej). Warto więc zwrócić uwagę na to, że bez uwzględnienia „warunków pierwotnych” oraz mogących występować $\mathrm{w}$ analizowanym obszarze związków przyczynowo-skutkowych, wszelkie dane uzyskiwane $\mathrm{w}$ toku badań ( $\mathrm{w}$ tym dotyczące porównań tych dwóch grup podmiotów) mogą wpływać na deformujące lub niepełne spostrzeżenia. Pominięcie powyższych związków może w konsekwencji skutkować fragmentarycznością lub wycinkowością badań oraz zniekształceniami na etapie wnioskowania.

$\mathrm{W}$ analizowanej problematyce istotnym zagadnieniem wydaje się przy tym rola oraz realne możliwości oddziaływania przez kierownika podmiotu leczniczego na podległych pracowników, co w istotnym stopniu może być determinowane powyżej opisanymi okolicznościami. Tymczasem bywa, że w przestrzeni publicznej, ale również w pracach naukowych, formułowane są opinie wiążące niedomagania publicznej ochrony zdrowia $\mathrm{z}$ niedostatkami kompetencyjnymi dyrektorów publicznych podmiotów leczniczych. W rezultacie, ze względu na lokalizację tego stanowiska niejako $\mathrm{w}$ centrum różnorodnych interakcji występujących na styku otoczenia wewnętrznego i zewnętrznego, na dyrektorach szpitali koncentrują się często negatywne skutki, pomimo że zazwyczaj są w istocie wynikiem mankamentów systemu ochrony zdrowia. Tutaj krzyżują się bowiem problemy determinowane związkami przyczynowo-skutkowymi kreowanymi przez poszczególne komponenty otoczenia zewnętrznego oraz uwarunkowania wewnętrzne. Jednakże biorąc pod uwagę okoliczności, w których działają menedżerowie szpitali publicznych, w tym dotyczące m.in.: jednoosobowej odpowiedzialności dyrektorów za zarządzany podmiot, specyficznej dla tego sektora rynkowości (niejednokrotnie implikującej funkcjonowanie poszczególnych podmiotów w warunkach permanentnego niedostatku środków finansowych bez możliwości, w tym ze względu na misyjność sektora, jednoznacznie racjonalnie ekonomicznie decydowania), sprzeczności oczekiwań ze strony różnych interesariuszy (m.in. równocześnie występująca presja w kierunku zwiększania kosztów pracy istotnie wpływających na pogarszanie sytuacji finansowej szpitala $\mathrm{z}$ równoczesnym naporem $\mathrm{w}$ kierunku poprawiania wyniku finansowego) czy nierzadko obserwowanego ograniczania autonomii decyzyjnej dyrektorów poprzez różnorodne oddziaływania, $\mathrm{w}$ tym polityczne, problem ewentualnych ocen w tym względzie wydaje się dużo bardziej złożony.

\author{
dr inż. Piotr Lenik \\ Państwowa Wyższa Szkoła Zawodowa \\ im. S. Pigonia w Krośnie \\ Instytut Politechniczny \\ e-mail: piotrlenik@vp.pl
}




\section{Bibliografia}

[1] Anthony R.N., Young D.W. (1998), Management Control in Nonprofit Organizations, Irwin/McGraw-Hill, Homewood.

[2] Buchelt B. (2011), Metody i narzędzia eliminacji dysfunkcji systemu zarzadzania zasobami ludzkimi sektora ustug medycznych, [w:] Z. Janowska (red.), Dysfunkcje i patologie w sferze zarządzania zasobami ludzkimi, t. 4, Wydawnictwo Uniwersytetu Łódzkiego, Łódź, s. 164-186.

[3] Frączkiewicz-Wronka A., Szymaniec K. (2012), Model interesariuszy $w$ zarzadzaniu zmianq $w$ szpitalach, [w:] Ł. Sułkowski, R. Seliga (red.), Kulturowe determinanty zarzadzania szpitalami w Polsce, Difin, Warszawa, s. 215-247.

[4] Gilbert D.R., Stoner J.A.F., Freeman E.R. (2011), Kierowanie, Wyd. Naukowe PWN, Warszawa.

[5] Głód G. (2016a), Uwarunkowania i pomiar przedsiębiorczości publicznej w jednostkach ochrony zdrowia, Difin, Warszawa.

[6] Głód G. (2016b), Innowacyjność ZZL w sektorze ochrony zdrowia - wybrane aspekty, „Nauki o Zarządzaniu”, $\mathrm{Nr}$ 1(26), s. 44-51.

[7] Golinowska S. (2012), Zarys systemu ochrony zdrowia. Polska 2012, www.akademia.nfz.gov.pl.

[8] Golinowska S. (2005), Ochrona zdrowia, [w:] Raport społeczny. Polska 2005, Fundacja im. Friedricha Eberta, Warszawa.

[9] Health at Glance Report - Europe 2018, http://www. oecd.org/health/health-at-a-glance-europe-23056088. htm, data dostępu: 01.12.2018 r.

[10] http://www.rynekzdrowia.pl/Polityka-zdrowotna/Raport-KE-OECD-nt-ochrony-zdrowia-w-UE-Jak-wypadamy - na-tle - innych, data dostępu: $14.01 .2018 \mathrm{r}$.

[11] Jasińska J. (2015), Zmiany w organizacjach. Sprawne zarządzanie, sytuacje kryzysowe i warunki osiagania sukcesu, Frel, Warszawa, s. 141-370.

[12] Jończyk J. (2011), Kształtowanie proinnowacyjnej kultury organizacyjnej w publicznych szpitalach, ,Zarządzanie Zasobami Ludzkimi", Nr 2, s. 44-54.

[13] Jończyk J. (2012), Zasoby ludzkie jako krytyczny komponent zmian $w$ opiece zdrowotnej, Prace Naukowe Uniwersytetu Ekonomicznego we Wrocławiu, Nr 266, s. 221-228.

[14] Kautsch M. (2015), Rady społeczne $i$ nadzorcze w opinii dyrektorów szpitali, „Zarządzanie Publiczne”, Nr 2(32), s. $54-65$.

[15] Koźmiński A.K., Piotrowski W. (2002), Zarządzanie. Teoria i praktyka, Wyd. Naukowe PWN, Warszawa.

[16] Lenik P. (2017), Zarządzanie ewolucyjnymi zmianami w szpitalach publicznych. Teoria i praktyka, Wolters Kluwer, Warszawa.

[17] Martyniak Z. (1987), Organizatorka, PWE, Warszawa.

[18] Moczydłowska J.M. (2016), Bariery zaangażowania organizacyjnego pracowników ochrony zdrowia $w$ opinii kadry kierowniczej, Zeszyty Naukowe WSH Zarządzanie, Nr 1, s. 172-180.

[19] OECD Health Statistic 2017 - http://stats.oecd.org/Index.aspx?DataSetCode=SHA, data dostępu: 17.02.2018 r.
[20] Porębski D. (2015), Pomiar efektywności ekonomicznej szpitala $z$ wykorzystaniem zintegrowanej karty wyników, Wyd. Uniwersytetu Ekonomicznego we Wrocławiu (maszynopis rozprawy naukowej).

[21] Słownik języka polskiego (1996), Wyd. Naukowe PWN, Warszawa, http://sjp.pwn.pl/slowniki/instytucjonalizacja.html, data dostępu: 23.02.2018 r.

[22] Stoner J.A.F., Wankel Ch. (1997), Kierowanie, Wyd. Naukowe PWN, Warszawa.

[23] Sułkowski Ł., Seliga R., Woźniak A. (2012), Kulturowe bariery zmian $w$ polskich szpitalach - rezultaty badań, [w:] Ł. Sułkowski, R. Seliga (red.), Kulturowe determinanty zarzadzania szpitalami w Polsce, Difin, Warszawa, s. $98-128$.

[24] Sułkowski Ł. (2013), Zmiana kulturowa w polskich szpitalach - wyniki badań, „Przedsiębiorczość i Zarządzanie”, tom XIV, zeszyt 10, część I, s. 83-96.

[25] Szwiec P. (2012), Kultura organizacyjna czy kultury organizacyjne? Podstawowe podejścia do kultury organizacyj$n e j$, „Przegląd Organizacji”, Nr 9, s. 7-11.

[26] Urbanowska-Sojkin E., Banaszyk P., Witczak H. (2007), Zarządzanie strategiczne przedsiębiorstwem, PWE, Warszawa.

[27] Ustawa o działalności leczniczej - podsumowanie dwóch lat funkcjonowania. Próba oceny skutków regulacji (2013), Instytut Organizacji Ochrony Zdrowia Uczelni Łazarskiego, Warszawa.

[28] Zadłużenie SPZOZ - http://www.mz.gov.pl/system-ochrony-zdrowia/organizacja-ochrony-zdrowia/zadluzenie-spzoz, data dostępu: 11.02.2018 r.

\section{Selected Obstacles Inhibiting Management Effectiveness in Public Hospitals}

\section{Summary}

The article deals with a very current problem of dysfunctionality of the national health care system, with particular attention to shortcomings occurring in the areas of management in public hospitals. The aim of the article is to analyse, based on the field research conducted throughout the country, the factors that determine managing public hospitals - including dysfunctions identified in the areas of human factor management in public healthcare entities. At the same time, it was assumed that, within the scope of the studied subject, dysfunctions and limitations may be the result of other factors than it might seem on the basis of a superficial analysis that does not take into account all circumstances that may affect the given state of affairs.

\section{Keywords}

hospital management, public health care, human capital management, human resources management, public management 